\title{
An Analysis of the Cost of Educational Wastages in Nigerian Public Universities: Efficiency in View
}

\author{
Dr. Oyetakin, Akinrotimi lyiomo \\ Department of Educational Management, Faculty of Education, \\ Adekunle Ajasin University, Akungba-Akoko, Ondo State, Nigeria \\ E-mail: daroyiomo@yahoo.com

\section{Dr. Odunayo Mabel Olufunmilayo}

Provost, Topmost College of Education, Ipaja, Lagos State, Nigeria

\section{Doi:10.5901/jesr.2013.v3n7p683}

\section{Abstract}

\begin{abstract}
The study examined the trend and social costs of educational wastage in public universities in Nigeria between 2008 and 2012. One major challenge confronting university education in Nigeria is that the total number of students enrolled for the academic session does not graduate at the specified period which has humongous social and private costs implication. Wastages across universities and areas of specialization have constituted a management problem and a drain at the limited resources in the Nigeria universities. As a survey method of descriptive research design and ex-post facto, it makes use of some indicators for measuring the wastage rate and the cost in Nigeria universities. Data were collected through the use of a validated selfdesigned questionnaire titled, Record and Financial Inputs and Output Questionnaire (SRFIOQ) with a reliability coefficient of $r$ $=0.89$. The study covered six universities (3 Federal and 3 States) among the eleven public universities in South West Nigeria selected through a purposive simple random sampling method. The participants cut across students in eight faculties of the sampled universities. Data were analyzed using frequency counts, simple percentage score and bar graphs and inferential statistics tools to test the research hypotheses for the study. The study revealed that there were variations in the wastage rate indicating a high percentage wastage rate which exists among faculties in various institutions under study. On the average, social cost on wastage was higher on male undergraduates with $N$ 451,951,012.60 than that of females N 302,807,178.40. There was a significant difference in the social cost of wastages between male and female undergraduates $(t-c a l=.512<t$-val= $.413 ; P<.05)$. Also, there was a significant difference in the social cost of wastages between the states and federal public universities ( $t$-cal $=1.439<t$-val= .874; $P<.05)$ from 2008 to 2012. It was therefore recommended that universities should endeavour to improve on their delivery of results as at when due in order to improve the internal efficiency of the institutions. Also, students' workload should be reduced and the idea of automatic promotion from one level to the next level which is in practice in Nigeria universities should be addressed.
\end{abstract}

Keywords: Wastage rate, internal efficiency, external efficiency, cost models, human capital.

\section{Introduction}

Originating from the language of the economists, the term "wastage" is used within the field of education to describe various aspects of failure of an educational system to achieve its objectives. Education is the key to change and progress; therefore, government of Nigeria has adopted this sector as one of the pillars for poverty reduction and benefits of. Annually, universities are allocated various financial and non-financial resources to carry out their primary functions of teaching, learning and research, but with the rapid expansion of the school system, increasing demand for more school buildings, more qualified and competent teachers, non-academic staff and instructional facilities for effective teaching and learning becomes inevitable. Therefore, the provision of these resources would further increase the cost of secondary education. According to Babalola (2001), Nigeria is among the countries where opportunities for human development have been missed, and reasons for this variation have been ascribed to political instability, economic mismanagement, widespread recession, rising interest rates and level of indebtedness. The argument against public subsidy in higher education was very strong, hence primary, secondary and higher education should receive the highest investment priority respectively which must not be eroded by high wastage rate.

Wastages according to Adamu (2000); Samuel (2004); and Oyetakin (2011), is an unprofitable and uneconomical 
utilization of time and resources. The inability of a student to obtain one's school certificate at the normal time for any reason, whatsoever is regarded as wastage. On the other hand, wastage means the input, time, efforts expended in doing things but with no positive outcomes or outputs. Educational wastages mean premature withdrawal of child or students from school at any stage before completion of the prescribed courses. This implies that within an academic year, some student's dropout of schools for various reasons. According to Education Sector Analysis, dropout/completion rate is one out of the five indicators with which the education system tries to actualize the philosophy of Nigerian Education masses (Federal Government of Nigeria, 2004). Pupils who repeat the same class while their mates proceed to higher classes in the next academic year and those who prematurely withdraw from secondary school before completion are considered as wastage. This wastage threatens the internal efficiency of the education system. It is a stumbling block to the realization of the nation's aims and objectives of university education.

According to Akangbou (1985), the phenomenon of high repetition is experienced in many third world countries and is an indicator of inefficiency of the educational system. He also maintained that repeating a class increases private and public cost of education shouldered by parents and the states and in addition leads to large classes with attendant problems of assessment and supervision of students, more facilities needed, training and recruiting more teachers and provision of additional didactic materials. Repetition of classes may have negative effect on students and parents, therefore, the development of every child must be directed towards the ability of the child-bearing in mind the needs of the society. Abilities and capabilities of students are not the same in every subject; therefore, teachers must endeavor to develop such child alongside his/her abilities and capabilities which may drastically reduce repetition and its associated frustration that might eventually degenerates to dropout of students from the school system.

The trend of dropout, repetition and failure, although observable all over Nigeria has become a syndrome in certain states of the federation. Akindele (2005) stated that the analysis of efficiency in education is necessary in ensuring optimal use of the meager resources allocated to education in order to eliminate or minimize wastage. The additional number of years spent by the repeaters in the course of repeating classes is also viewed as wastages. One major problem confronting university education in Nigeria is that the total number of students enrolled for a particular academic session does not graduate from at the specified period.

\section{Efficiency and Wastages}

A major application of economic analysis is to inform decision-making in education in order to improve efficiency in educational production; that is, producing more desired education outputs and outcomes given educational resources. Analytically, educational efficiency can be distinguished as internal efficiency and external efficiency. Internal efficiency relates educational outputs to educational inputs, while external efficiency relates educational outcomes to educational inputs. Analysis of educational efficiency is not confined to economic concerns only, since educational outputs and outcomes also pertain to social and political dimensions of national development. The internal efficiency of education is improved when more education outputs are produced at given education resources or fewer education resources are used in producing the same amount of education outputs. Thus, educational economic analysis is centrally concerned with the production of education outputs and with education costs. An educational production function is a mathematical construct that mainstream economists and researchers from other disciplines often use to study educational production. It relates some measure of education output (e.g., student achievement) to various inputs used in education such as student characteristics and family background, teacher characteristics and other school-related factors.( Afriat, 1972; Battese, 1992; and Famade,2003; Oyetakin, 2010).

The external efficiency of education is improved when more education outcomes are produced at given education resources or fewer education resources are used in producing the same amount of education outcomes (Oyetakin, 2011). During the closing decades of the twentieth century, emphasis in developing nations regarding educational development has been placed on three broad outcomes of education: contribution to economic growth and competitiveness, improvement in social equity, and poverty alleviation.

Psacharopoulos (1994) in a study on rate of returns, found that in developing nations education had a high rate of return and that the returns varies according to the education levels. According to human capital theory, education is a form of human capital that could raise the productive capacity of individuals in economic production. Empirical studies in agriculture found a positive and significant relationship between productivity and education. At the macro level, education was also associated with economic growth. Spending on education can be seen as an investment activity with both costs and benefits, and thus subject to a cost-benefit analysis.

The composite nature of the error term in the stochastic model also has very helpful implications in the analysis of 
school district cost structure. For example, Bradbury et al. (1984) and Downes and Pogue (1994) included environmental cost factors in cost models, and thus tried to identify the cost differential between local jurisdictions (municipalities, school districts, cities and towns) because of uneven environmental cost factors. In the case of education, it might be that in one school district there is an extra cost of $\$ R$ per pupil due to a particular environmental cost factor such as the presence of special-need students. There may be agreement among state and local officials that this $\$ R$ per pupil should be covered by the state aid formula. However, it is reasonable to ask under what random favorable or unfavorable conditions a particular school district is operating. In Nigeria, costs of education has being increasing at an increasing rate due to the ever teeming population of over 150 million which has a multiplier effect on the school enrolment. Hence, cost saving measures should be adhered to by all levels of education since this will go a long way to improving the quality and efficiency of the education system in the country (Oyetakin, 2007).

\section{Statement of the Problem}

One major problem confronting university education in Nigeria is that the total number of students enrolled for the academic session does not graduate at the specified period which has humongous social and private costs implication. Wastages across universities and areas of specialization have constituted a management problem and a drain at the limited resources in the Nigeria universities. Experience shows that some of these students repeat classes/courses because of poor academic performance arising from long absence from school while some of the students eventually dropout of school and the huge public expenditure on students who do not attend school regularly and those who dropout from school system affects the internal efficiency of the universities.

\section{Purpose of the Study}

One major problem facing the educational sector in the country is the problem of educational wastages caused by dropout, repetition and failure. The present study is designed to explore the problems and cost of wastages in education The researcher therefore attempted to undertake this study in order to ascertain:

- The rates of educational wastages in the area of study?

- Social cost of educational wastages in Nigeria between 2008 and 2012

- A study of this nature would also shed more light on the financial implications of educational wastages in South West Nigeria public universities and how efforts should be made in eliminating or reducing wastage drastically in the country.

\section{Research Questions}

The study therefore is concerned with answering the following questions:

1) Was there any difference in the social cost of wastages between male and female undergraduates in South West Nigeria public universities from 2008 to 2012?

2) Was there any difference in the social cost of wastages between Federal and State Universities students in South West Nigeria from 2008 to 2012?

\section{Hypotheses}

H.01 There was no significant difference in the social cost of wastages between male and female undergraduates of public universities South West Nigeria between 2008 and 2012.

H.02 There was no significant difference in the social cost of wastages between the states and federal public universities in South West Nigeria from 2008 to 2012.

\section{Methodology}

\subsection{Design}

Descriptive research design was used with survey methods. 


\subsection{Sample and Sampling Techniques}

Nigeria is made up of six geo-political zones namely: North-West, North-East, North-Central, South-South, South-East, and South-West. Thus, a purposive simple random sampling method was adopted and the South-West geo-political zone was selected out of which six universities (3 Federal and 3 States) were randomly selected among the eleven public universities. In each of these universities, the Academic planning unit and Bursary supplied the needed data on students' enrolment and graduation. Also, the Bursaries of these institutions supplied the audited account profile on the undergraduates which aided the analysis.

\subsection{Instrumentation}

For data gathering, the instrument used was a self constructed questionnaire titled: "Students' Record and Financial Inputs and Output Questionnaire" (SRFIOQ). The SRFIOQ contains five parts: A, B, C, D and E. Part A seeks information on Enrolment, Repeaters and Drop-out. Enrolment per class/level and per year from 2008 to 2012, where the total enrolment per level and per year were calculated, likewise total failure per year and total drop-out per year were computed. Part B demands data relating to financial inputs on education in schools, different sources of income (financial inputs) and the amount per year from 2008 to 2012.

Part C, seeks information on the academic achievement of the students at the end of their final year. The 2008 and 2012 final results were collected. Total number of students that sat for the examination per year and total number of students that graduated at the specified period of study was compiled. Part D, seeks the opinion of the university management on the adequacy of physical facilities in the school such as spacious and well ventilated classrooms, well equipped laboratories and library. Before administration, the instrument was validated and found reliable at $r=0.86$. The statistical tool applied were descriptive and inferential statistics, mean and t-tests were employed to test the hypotheses, the level of significance used on the study was the 0.05 alpha.

\subsection{Results}

1. Was there any difference in the social cost of wastages between male and female undergraduates in South West Nigeria from 2008 to 2012 ?

Table 1: Average Refined Social Cost of Undergraduates by Gender Adjusted for Wastage by Faculties in South West Nigeria Universities from 2008 to 2012

\begin{tabular}{lccccccc}
\hline Faculty & \multicolumn{2}{c}{ \% Wastage Rate } & \multicolumn{2}{c}{ Cost (A) } & \multicolumn{2}{c}{ \% by Faculty } \\
& Male & Female & Total & Male & Female & \\
\hline Arts & 21 & 25 & 46 & $51,114,485.73$ & $60,850,578.25$ & 12.30 \\
Adm/Mgt. & 25 & 27 & 52 & $60,809,754.00$ & $65,674,543.32$ & 13.90 \\
Education & 15 & 11 & 26 & $36,492,110.40$ & $26,760,880.96$ & 6.95 \\
Engineering & 22 & 18 & 40 & $56,960,516.80$ & $46,604,059.20$ & 10.70 \\
Law & 25 & 29 & 54 & $60,792,360.25$ & $70,519,137.88$ & 14.44 \\
Medicine & 21 & 26 & 47 & $54,376,041.30$ & $67,322,717.80$ & 12.57 \\
Sciences & 33 & 24 & 57 & $80,323,635.81$ & $62,144,047.20$ & 15.24 \\
Social Sc. & 21 & 31 & 52 & $51,082,108.35$ & $75,406,921.85$ & 13.90 \\
\hline Total & $\mathbf{1 8 1}$ & $\mathbf{1 9 1}$ & $\mathbf{3 7 4}$ & $\mathbf{4 5 1 , 9 5 1 , 0 1 2 . 6 0}$ & $\mathbf{3 0 2 , 8 0 7 , 1 7 8 . 4 0}$ & $\mathbf{1 0 0}$ \\
\hline
\end{tabular}

Source: Fieldwork

Table1 reveals that a high percentage wastage rate exists among faculties in various institutions under study. On the average, social cost on wastage was higher on male undergraduates with $N 451,951,012.60(2,824,693.83$ USD) than that of females N 302,807,178.40 (1,892,544.87 USD). However, highest percentage wastage was recorded among males in the Faculty of Science with $33 \%$ followed by Social science with females recording $31 \%$. 
Figure 1: Wastage Rate of Undergraduates by Gender in Faculties of Public Universities in South West Nigeria from 2008 to 2012

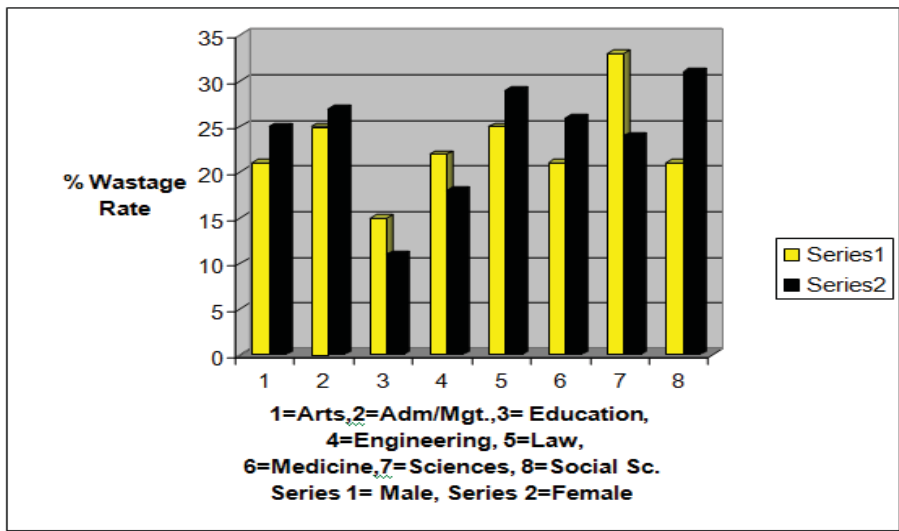

Source: Derived from Table 1

2. Was there any difference in the Social unit cost of wastages between Federal and State Universities students in South west Nigeria from 2008 to 2012?

Table 2. Average Social Cost of Wastage of Undergraduates by Faculties between Federal and State Universities in South West Nigeria from 2008 to 2012

\begin{tabular}{lcccccc}
\hline Faculty & \multicolumn{2}{c}{ \% Wastage Rate } & \multicolumn{2}{c}{ Cost (N) } & \multicolumn{2}{c}{ \% by Faculty } \\
& Male & Female & Total & Male & Female & \\
\hline Arts & 21 & 25 & 46 & $51,114,485.73$ & $60,850,578.25$ & 12.30 \\
Adm/Mgt. & 25 & 27 & 52 & $60,809,754.00$ & $65,674,543.32$ & 13.90 \\
Education & 15 & 11 & 26 & $36,492,110.40$ & $26,760,880.96$ & 6.95 \\
Engineering & 22 & 18 & 40 & $56,960,516.80$ & $46,604,059.20$ & 10.70 \\
Law & 25 & 29 & 54 & $60,792,360.25$ & $70,519,137.88$ & 14.44 \\
Medicine & 21 & 26 & 47 & $54,376,041.30$ & $67,322,717.80$ & 12.57 \\
Sciences & 33 & 24 & 57 & $80,323,635.81$ & $62,144,047.20$ & 15.24 \\
Social Sc. & 21 & 31 & 52 & $51,082,108.35$ & $75,406,921.85$ & 13.90 \\
\hline Total & $\mathbf{1 8 1}$ & $\mathbf{1 9 1}$ & $\mathbf{3 7 4}$ & $\mathbf{4 5 1 , 9 5 1 , 0 1 2 . 6 0}$ & $\mathbf{3 0 2 , 8 0 7 , 1 7 8 . 4 0}$ & $\mathbf{1 0 0}$
\end{tabular}

Source: Fieldwork

Table 2 shows that State Government owned universities had the highest percentage of wastage in all faculties except sciences with Federal universities recording a higher percentage of 30 while the State had $27 \%$. The average wastage for State owned universities was $25.75 \%$ with a total social cost implication was N 340.604,903,20 (2,128,780.65USD) and average social cost of $\mathrm{N} \mathrm{42,575,612.90}$ (266,097.58 USD). While the Federal owned universities recorded a total social cost of wastage to be $\mathrm{N} 286,293,621.90$ (1,789,335.14 USD) and an average social cost of wastage as $\mathrm{N}$ $35,786,702.74(233,666.89$ USD).

\section{Testing of Hypotheses}

\subsection{Hypothesis One}

There was no significant difference in the social cost of wastages between male and female undergraduates of public universities in South West Nigeria between 2008 and 2012. 
Table 3. Summary of the Difference in the Social Cost of Wastages between the Male and Female Undergraduates in South West Nigeria Public Universities from 2008 to 2012

\begin{tabular}{lccccccc}
\hline Source & Mean & S D & SEM & df & t-cal & t-val & Sig. \\
\hline Male & 37850896.94 & 8275671.57 & 2925891.74 & & & & \\
& & & & 14 & .512 & .413 & $P<.05$ \\
Female 39804940.99 & 10504502.77 & 3713902.57 & & & & & \\
\hline * Significant & &
\end{tabular}

In analyzing the social cost of wastages between male and female undergraduates, the t-test analysis was performed with the results showing the mean for male as 37850896.94 and 39804940.99 for female. The t-calculated was .512 and $\mathrm{t}$-table was .413. Since the t-calculated value was greater than the t-table, the hypothesis is therefore rejected. (t-cal= $.512<\mathrm{t}$-val $=.413 ; \mathrm{P}<.05)$. Hence, there was a significant difference in the social cost of wastages between male and female undergraduates of public universities South West Nigeria between 2008 and 2012.

\subsection{Hypothesis Two}

There was no significant difference in the social cost of wastages between the states and federal public universities in South West Nigeria from 2008 to 2012.

Table 3. Summary of the Difference between the mean of Male and Female Direct Private Unit Cost of Undergraduates in South West Nigeria Public Universities from 2008 to 2012

\begin{tabular}{lccccccc}
\hline Source & Mean & S D & SEM & df & t-cal & t-val & Sig. \\
\hline Federal & 35786702.74 & 8891600.24 & 3143655.41 & & & & \\
& & & & 14 & 1.439 & .874 & $\mathrm{P}<.05$ \\
State & 42575612.90 & 9946704.33 & 3516691.04 & & & & \\
& & & & & & & \\
\hline * Significant
\end{tabular}

Table 4 reveals that the mean of male undergraduate social cost of wastages in public universities was 35786702.74 for Federal Universities. While that of the State was 42575612.90 . The $t$-calculated value is .1 .439 and t-table is .874 . Since the $t$-calculated value was greater than the $t$-table, the hypothesis is therefore rejected. ( $t$-cal $=1.439<t-v a l=.874 ; P<.05)$. Hence, there was a significant difference in the social cost of wastages between the states and federal public universities in South West Nigeria from 2008 to 2012.

\section{Discussion and Conclusion}

The study revealed that the variations in the costs and cost of wastages between the federal and State owned universities in Nigeria. Also, female undergraduates recorded the highest percentage wastage when compared with their male counterparts. This result is corroborated by the findings of Adamu (2000) and Aina, Oyetakin, and Osun (2010).

Therefore, to reduce educational wastages in universities, the internal efficiency of education systems must be improved. Also, yearly drop-out, repeaters, make the planned development of the University System as impossible task; the total estimate on the cost of teachers, classrooms and other facilities that are used up in a non-profitable investment remains a threat to the financial efficiency of the institutions involved over a given period of time.

Hence, the financial implications of this educational wastage on public universities is that the amount wasted on students repeating a particular class, twice or even thrice, or inability to complete their course (Repetition) or failure, ought to have been put into useful production, if not because of the wastage. UNESCO (2011) pointed out that wastage is increasing the social and household expenditure on education in Sub-Saharan Africa, Nigeria inclusive. Hence, the money spent on the wasted undergraduates could have either been used in developing other sectors, such as building new classrooms, provision of modern and well equipped libraries, provision of modern, relevant and related textbooks etc. 


\section{Recommendations}

1. Universities should endeavour to improve on their delivery of results as at when due in order to improve the internal efficiency of the institutions.

2. Also, students' workload should be reduced and the idea of automatic promotion from one level to the next level which is in practice in Nigeria universities should be addressed.

3. The management of universities in Nigeria should also assess the cost-benefit analysis of university undergraduate education and encourage government at both state and federal to divert the hard-earned resources on wasted to other profitable education ventures and make undergraduate pay higher tuition in order to increase the private cost and thus reduce the social cost expended on wastages.

4. Introduction of cost-sharing and cost augmentation for social cost recovery on those repeating courses and classes. The argument is that parents/students involved in the act of wastages will be cautioned and there will be improvements which will inturn increase internal and external efficiency.

\section{Implication for Practice}

The outcome of this study shows that the cost of wastages in public universities is a drain on the limited financial and material resources. Hence, the recommendations of the study should be implemented in order to increase the internal and external efficiency of the system.

\section{References}

Adamu, B. (2000). Financial Implication of Educational Wastage in Secondary Schools in Ondo State. Journal of Professional Educators 1 (1a) $9-15$.

Afriat, S.N. (1972). Efficiency Estimation of Production Functions, International Economic Review, Vol.13, No. 3, (October).

Aina, S, Oyetakin, A.I. and Oshun, G.O (2010), Impact of Economic Depression on the Education of Male and Female Undegraduate in Nigeria, The Social Sciences Medwell Journal, Pakistan, 4(6), 610-613.

Akangbou, S. D. (1985), The Economics of education planning in Nigeria. New Delhi: Vika Publishing House. PT. Limited.

Akindele, J. B. (2005). Efficiency of Human Capital in Education, Kogi: Track Times Press.

Babalola, J.B. (2001). Global Transformation in Today's World: Implication for Financing Higher Education in Developing Economies, Ibadan: His Lineage Publishing House.

Battese, G.E. (1992). Frontier Production Functions and Technical Efficiency: A Survey of Empirical Applications in Agricultural Economics, Agricultural Economics, (7),185-208.

Bedi, A. S. \&Garg A. (2000). The effectiveness of private versus public schools: The case of Indonesia. Journal of Department of economics, 69(2), 463-494.

Bradbury, et al. (1984). State Aid to Offset Fiscal Disparities Across Communities, National Tax Journal, Vol. 37, (June).

Downes, T.A. and T.F. Pogue. (1994). Adjusting School-Aid Formulas for the Higher Cost of Educating Disadvantaged Students, National Tax Journal, Vol. 47, (March).

Famade, O. A. (2003). Measuring Productivity of Secondary Education in Ogun State, Nigeria. Journal of Education Thought. 3(1) 399407.

Federal Republic of Nigeria (2004) National Policy of Education,4th edition, Lagos: NERDC Press.

Oyetakin, A.I.(2007).Financial Implication of the Universal Basic Education Policy in Lagos: Economic Feasibility of the Scheme, Journal of Research in Educational Management, Lagos State University, Ojo, Vol.1(3), 112- 122.

Oyetakin (2010). Cost of Education: Determinant Of Free Education And Human Infrastructure In Nigeria, Education Thought, Faculty of Education, Adekunle Ajasin University, Akungba Ondo State, Nigeria.

Oyetakin, A.I. (2011). Cost of Education: Determinant of Free Education and Human Infrastructure in Nigeria, Educational Thought, Faculty of Education, Adekunle Ajasin University. Vol. 8 (1),171-185.

Psacharopoulos, G. (1994). Returns to Investment in Education: A Global Update. World Development 22:1325-1343.

Samuel, T. (2004). Repositioning Education in Lagos State for Improved Service Delivery: A Synopsis of Contending Issue and Policy Imperatives, TESCOM NEWS, 9(2), 